\title{
DOES THE AIDS EPIDEMIC REALLY THREATEN ECONOMIC GROWTH?
}

David E. Bloom

Ajay S. Mahal

Working Paper No. 5148

\author{
NATIONAL BUREAU OF ECONOMIC RESEARCH \\ 1050 Massachusetts Avenue \\ Cambridge, MA 02138 \\ June 1995
}

\begin{abstract}
An earlier version of this paper was presented at the Asian Development Bank. Financial support from the United Nations Development Programme is gratefully acknowledged. Mireille Jacobsen and Janhavi Dabholkar provided helpful research assistance. Paul Gertler, Sherry Glied, Jeffrey Sachs, and participants in the economic development workshop at Harvard University provided helpful comments. This paper is part of NBER's research programs in Health Care and Labor Studies. Any opinions expressed are those of the authors and not those of the National Bureau of Economic Research.

(c) 1995 by David E. Bloom and Ajay S. Mahal. All rights reserved. Short sections of text, not to exceed two paragraphs, may be quoted without explicit permission provided that full credit, including $\odot$ notice, is given to the source.
\end{abstract}




\title{
DOES THE AIDS EPIDEMIC REALLY THREATEN ECONOMIC GROWTH?
}

\begin{abstract}
This study examines the claim that the AIDS epidemic will slow the pace of economic growth. We do this by examining the association, across fifty-one developing and industrial countries for which we were able to assemble data, between changes in the prevalence of AIDS and the rate of growth of GDP per capita. Our analysis uses well-established empirical growth models to control for a variety of factors possibly correlated with AIDS prevalence that might also influence growth. We also account for possible simultaneity in the relationship between AIDS and economic growth.

Our main finding is that the AIDS epidemic has had an insignificant effect on the growth rate of per capita income, with no evidence of reverse causality. We also find evidence that the insignificant effect of AIDS on income per capita is qualitatively similar to an insignificant effect on wages of the Black Death in England and France during the Middle Ages and an insignificant effect on output per capita of influenza in India during 1918-19.
\end{abstract}

David E. Bloom

Department of Economics

Columbia University

New York, NY 10027

and NBER
Ajay S. Mahal

Department of Economics

Barnard College

New York, NY 10027 


\section{Does the AIDS Epidemic Really Threaten Economic Growth?}

The World Health Organization (WHO) estimates that by late 1994 nearly 18 million people worldwide had been infected by the human immunodeficiency virus (HIV) that causes AIDS, with a cumulative total of more than 4 million cases of full-blown AIDS (WHO 1995). WHO also projects significant future spread of HIV, with a cumulative global total reaching 30 to 40 million people by the year 2000 (WHO 1994a). Even more alarming is the Mann, Tarantola, and Netter (1992) projection of 110 million cumulative cases of HIV infection worldwide by the year 2000 .

Although biomedical and public health issues continue to dominate the agenda of AIDS researchers, recognition has grown in recent years that the epidemic is more than just a health problem, but is also a problem with deep economic roots and potentially serious economic consequences. Throughout the world, relatively high rates of HIV infection among sex workers, injecting drug users, long-haul truck drivers, commercial blood donors, migrant workers, sailors, and fishermen provide compelling evidence of the interplay between economic forces and HIV transmission (see Barnett and Blaikie 1992; Bloom and Lyons 1993; Bloom and Mahal 1995; Mann, Tarantola, and Netter 1993; The Panos Institute 1992; Philipson and Posner 1993; World Bank 1992, 1993a). Moreover, research on the economic implications of the AIDS epidemic is increasingly being guided by models built around the observation that $\mathrm{HIV}$ is transmitted as a direct by-product of purposeful behavior, not randomly, as in the case of most other infectious diseases (see Bloom and Glied 1989; Bloom and Mahal 1995; Kremer 1995; Philipson and Posner 1993). Economic research also indicates that the per case medical care costs of AIDS are high 
relative to the costs of diagnosing and treating other serious illnesses (Bloom and Carliner 1988; Bloom and Lyons 1993; Hellinger 1993; The Panos Institute 1992). Added to these costs are the private income and social output losses associated with AIDS-related morbidity and mortality, which tend to be large because prime-age individuals are disproportionately represented among AIDS cases (Bloom and Mahal 1995; WHO 1994a). The costs are further magnified by the need to maintain sterile medical practices, blood testing, education for prevention campaigns, and basic research on AIDS (Bloom and Carliner 1988; Bloom and others 1995; The Panos Institute 1992; Sisk 1988; World Bank 1992).

Many influential AIDS experts contend that the epidemic will have a substantial negative impact on national economic well being. These experts fall into two groups. The first group consists of those who infer this result from the combination of large projected numbers of prime-age seropositive individuals and the relatively high estimated cost of medical care for persons with AIDS For example, Philipson and Posner (1993) assert that because of the epidemic's size, its distinctive economic character in parts of Africa and, in the near future, in Asia as well, will be its substantial implications for such key indicators of macroeconomic performance as economic growth, GNP, and GNP per capita. The various United Nations agencies working on the economic and development implications of the epidemic express similar views. For example, the World Bank (1993a, p. 100) states that "AIDS, affecting as it does mainly people in the economically productive adult years, has powerful negative economic effects on ... countries." Similarly, the United Nations Development Programme (UNDP) claims that "the extent of illness and death caused by the epidemic could deplete critical sectors of the labour force, ..., and adversely affect every sector of the economy. The 
consequences of the spread of the virus will be inexorable and awesome" (UNDP 1992, p. 1). The UNDP also argues that "the AIDS epidemic imposes large costs on individuals and their families that will be translated into aggregate costs that could become large enough to create national economic crises." (Lyons 1993, p. 5). Finally, the former head of WHO's Global Programme on AIDS, Michael Merson, has said the "deaths of millions of able-bodied adults will ... rob society of their education, skills, and experience. The resulting productivity losses will ... threaten the very process of development" (Merson 1992, p. 2). [1]

The second group of experts derive conclusions from data analyses guided by well-established economic models customized in various ways to fit the AIDS epidemic as it is projected to evolve. For example, Kambou, Devarajan, and Over (1992) simulate the impact of the AIDS epidemic using an eleven-sector computable general equilibrium model of Cameroon. They assume that the AIDS epidemic claimed the lives of 30,000 workers (or 0.8 percent of the labor force) each year from 1987 to 1990 , with deaths occurring disproportionately among the more skilled segments of the workforce. For example, they assume that 6.0 percent of the skilled urban workforce died of AIDS each year, compared to 0.4 percent of the unskilled rural labor force. In this simulation, the AIDS epidemic lowers the rate of growth of GDP by nearly 2 percentage points per year.

Cuddington (1993) and Cuddington and Hancock (1994) use a standard neoclassical growth model to explore the effect of AIDS on economic growth. In this model AIDS-related morbidity and mortality decrease the size of the labor force. In addition, AIDS-related medical expenditures lower public and private savings, leading in turn to reduced investment in physical capital and lower 
productivity. These studies focus on the epidemic's impact in Tanzania and Malawi, countries whose AIDS epidemics are among the most severe in the world. These studies indicate that AIDS will depress the annual growth rate of real GDP per capita by an average of one-fourth of 1 percentage point through the year 2010 (the mid-point of their low and high scenarios) assuming that World Bank projections of the number of AIDS cases are realized.

Applying a related framework to data for sub-Saharan Africa, Over (1992) assumes that AIDS cases will be disproportionately concentrated among the more educated classes and also that 50 percent of AIDS medical care costs will be financed by reduced savings (which translates into reduced investment and a slower rate of expansion of economic capacity). He concludes that the epidemic will depress growth rates of GDP per capita in Africa by roughly 0.15 percentage points per year ( 0.33 percentage points under a worst-case scenario), a sizeable amount in the context of sub-Saharan Africa's recent growth experience (that is, a 1.2 percent average annual decline in income per capita from 1980 to 1991). [2]

Notwithstanding the consensus that emerges from these studies, there are good reasons to suspect that they overstate the seriousness and immediacy of the threat AIDS poses to economic growth. First, the surplus labor in many developing countries could mitigate output losses that might otherwise be associated with AIDS morbidity and mortality. [3]

Second, although it is not yet definitively established, a link between HIV infection and poverty appears to be emerging (see Bloom and Glied 1993 and Over and Piot 1993). Indeed, many studies have found that the more educated exhibit superior knowledge of HIV and AIDS and a greater willingness to take precautions against contracting HIV than the less educated (Ahituv, Hotz, 
and Philipson 1993; also see references cited in Philipson and Posner 1993). This link suggests that AIDS-related output losses, income losses, and medical expenditures will be relatively low on a per case basis, corresponding to the relatively low productivity, earnings, and utilization of medical services among the poor (Bloom and Glied 1993; Bloom and others 1995; Griffin 1990; Philipson and Posner 1993).

Third, normal social and economic adjustments will tend to mitigate the costs of the epidemic. For example, community-based organizations and extended family networks have emerged as one mechanism for coping with the requirements for medical treatment associated with the epidemic. These mechanisms, which have arisen in widely diverse settings, often provide health services more efficiently than the formal health care system (see Barnett and Blaikie 1992; The Panos Institute 1992; World Bank 1993a).

Fourth, although AIDS medical care costs may be drawn disproportionately from personal savings in the short run, one would expect these costs to fall less heavily on savings in the longer run. Finally, one might reasonably expect AIDS case projections to overstate the eventual number of cases as individuals perceive and respond to the disincentives associated with behaviors that put them at high risk for contracting HIV (Bloom and Glied 1992; Philipson and Posner 1993). For example, a recent medium-scenario projection for Thailand of 1.4 million cumulative HIV cases by the year 2000 (Brown and others 1994) is considerably smaller than the 2 to 4 million cumulative cases that had been projected in 1992 (Viravaidya, Obremsky, and Myers 1993). Similarly, Bloom and Glied (1992) demonstrate that AIDS case projections constructed for the United States by various researchers in the 1980 s overpredicted by 15 to 93 percent the number of new AIDS cases in 
1991 (Bloom and Glied 1992, p. 344). They also show that the divergence of actual and projected AIDS cases is substantially attributable to reduced levels of high-risk behavior. The same conclusion presumably applies to the case of Thailand also as condom utilization among commercial sex workers increased from under 50 to 94 percent between 1989 and 1993 and the reported nationwide incidence of sexually transmitted diseases dropped precipitously from 6.5 to 1.6 per 1,000 population over the same period (Rojanapithayakorn 1994).

This study contributes to the existing literature on the impact of the AIDS epidemic on economic growth by estimating that impact directly from cross-country data on AIDS and economic growth, avoiding the pitfalls of simulation models and their reliance on assumptions that are often difficult to justify. As the AIDS epidemic is now in its second decade and researchers have carried out comparable scientifically designed surveys on HIV prevalence in a number of countries, such an approach is feasible. To this end, we assembled national-level data on HIV and AIDS and built a new data set that allows us to link them to economic data for fifty-one industrial and developing countries. Our analysis uses well-established empirical growth models to measure the nature and strength of statistical associations between the prevalence of AIDS and the rate of growth of GDP per capita, controlling for other factors possibly correlated with AIDS prevalence that might also influence growth. We examine the sensitivity of the results to alternative timeframes and indicators of the size of the AIDS epidemic. We also account for the possibility of simultaneity bias caused by the effect of economic growth on HIV transmission, as well as for possible nonlinearities in the relationship between HIV prevalence and economic growth.

Our main finding is that the AIDS epidemic has had a statistically insignificant effect on the 
growth rate of per capita income, controlling for other factors that influence economic growth. We also find evidence that this effect on income is qualitatively similar to that of the Black Death in England and France during the Middle Ages and of influenza in India during 1918-19.

\section{METHODOLOGY}

\section{Data}

Data on the numbers of cases of HIV infection and AIDS are not readily available for different countries. Although many countries have reporting systems for HIV and AIDS, the figures are more an indication of the amount of HIV testing that has been done, the capacity of different medical systems to detect HIV infection or AIDS, and the efficiency of disease reporting systems (for example, length of reporting lags and degree of under-reporting) than of the true extent of the epidemics (Bloom and Glied 1992; Chin 1995; Peterson and Sarda 1995; WHO 1994a). Indeed, the true number of HIV and AIDS cases is often estimated to be 30 to 100 times the number of reported cases (Bloom and Mahal 1995; Peterson and Sarda 1995; WHO 1994b).

To monitor the extent and spread of HIV infection, many countries have established special HIV surveillance systems (Bloom and others 1995; Viravaidya, Obremsky, and Myers 1993; WHO 1994a,b). A number of these systems, especially those in developing countries, benefit from financial and technical assistance provided by WHO (Snell, Supran, and Tamashiro 1992). Under these so-called sentinel surveillance systems, blood tests for HIV are performed for representative samples of groups that are thought to be at risk for HIV infection, for example, blood donors, injecting drug users, pregnant women, and commercial sex workers. Coupled with estimates of the size of these 
groups, the resulting data can be used to construct national estimates of HIV prevalence among adults (that is, the proportion of the adult population that is HIV positive).

The HIV and AIDS data we analyze were assembled from several sources. We obtained national HIV estimates for adult HIV cases in African countries mainly from a report published by the United States Bureau of the Census' Center for International Research (U.S. Bureau of Census 1994), and supplemented by other sources (Barnett and Blaikie 1992; WorldAIDS 1993; U.S. Bureau of the Census 1993). Estimates of the numbers of adult HIV cases in Asian countries are based on data provided either individually by national AIDS committees or by WHO regional offices Adult HIV prevalence rates for countries in Europe and North America are drawn from Mann, Tarantola, and Netter (1992) and WorldAIDS (1993). HIV estimates for the two Latin American countries in the sample are from WorldAIDS (1993). In total, we have identified fifty-one countries for which reliable adult HIV prevalence estimates are available for the early 1990s (see table 1 for the list of countries). As there are no more than a handful of countries for which HIV prevalence estimates are available for multiple years going back to the mid-1980s, a panel data analysis is effectively ruled out.

Direct measures of the number of AIDS cases are not available for any country in our sample, with the exception of the United States. However, using standard epidemiological models, one can estimate the numbers of AIDS cases from (1) national estimates of HIV cases at a point in time, (2) available information on the distribution of the lag between HIV infection and the onset of AIDS, and (3) information on the time path of new infections in the country.

We used EPIMODEL, a standard package developed by James Chin (former chief 
epidemiologist of WHO's Global Programme on AIDS) and S. K. Lwanga, to estimate cumulative AIDS cases from HIV cases. EPIMODEL requires data on the year in which the HIV epidemic began (or, more precisely, when the number of HIV cases first exceeded 1 percent in some subpopulation), the number of HIV cases at some later point in time, and the year in which new cases of HIV infection are expected to reach their peak. (EPIMODEL assumes the time series of new HIV infections follows a gamma function $\frac{t^{(\alpha-1)} e^{-t}}{(\alpha-1) !}$, where $t$ refers to time). Depending upon the value of $\alpha$, its single parameter, this function can take on a wide range of shapes, with higher integer values of $\alpha$ corresponding to more rapid increases in HIV incidence in the epidemic's early stages. [4] Using data on the progression from HIV infection to AIDS among members of the San Francisco cohort study, EPIMODEL forward calculates AIDS cases from the time series it generates on new HIV infections (Chin and Lwanga 1991). [5]

To estimate the year the epidemic began, we use WHO estimates of the year in which HIV established itself in each region, adjusted for cross-country differences within the region in either the year in which the first AIDS case was reported (Mann, Tarantola, and Netter 1992; U.S. Bureau of the Census 1993) or the first year in which more than 1 percent of a sample of individuals in the country tested positive for HIV, depending upon the data available. EPIMODEL estimates of cumulative AIDS cases for 1992 are divided by each country's population to yield an estimate of national AIDS prevalence (see Chin 1994 and Chin and Lwanga 1991 for further details about EPIMODEL).

The data on HIV and cumulative AIDS prevalence are matched to economic and other social 
and demographic data for corresponding countries reported in Baron (1989); the 1989 PCGlobe database (see Kraas-Schneider 1989); the Heston-Summers data set (Version 5.5, Summers and Heston 1991); Human Development Report (UNDP 1994); World Population Prospects (United Nations 1993); the World Bank social indicators database 1993; World Tables 1993 (World Bank 1993b); and World Development Report (World Bank various issues).

We include data on rates of growth of per capita GDP and its determinants, such as indices of human capital (for example, average years of schooling and literacy rates), public sector investment in defense and education, degree of openness (ratio of imports plus exports to GDP), and levels of per capita income. We also include data on tourist flows, indicators of health status, level and growth of urbanization, religious affiliation of the population in each country (the percentage Christian or Muslim), population rates of growth, and birth and death rates.

\section{Empirical Model}

The main goal of our analysis is to obtain a consistent estimate of $\beta_{1}$ in the context of the following model:

$$
\begin{aligned}
& G D P_{i}=\beta_{0}+\beta_{1} A I D S_{i}+X_{i} \lambda+\varepsilon_{i} \\
& A I D S_{i}=E\left(\alpha_{k}, H I V_{i}, F H I V_{i}, P H I V_{i}\right) \\
& H I V_{i}=\delta_{0}+\delta_{1} G D P_{i}+Z_{i}\left(G D P_{i}\right) \delta_{2}+R_{i} \delta_{3}+\mu_{i}
\end{aligned}
$$

where

GDP is the rate of growth of real per capita gross domestic product;

AIDS is the annual average increase in the cumulative prevalence of AIDS; 
$\mathrm{X}$ is a vector of variables that influence economic growth;

$\mathrm{Z}$ and $\mathrm{R}$ are vectors of variables that may influence HIV transmission patterns, some of which may depend upon the rate of growth of per capita GDP;

FHIV measures the number of years between when HIV first established itself in the country and when HIV prevalence is measured;

PHIV measures the number of years between when HIV first established itself in the country and when the peak number of new HIV cases is projected to occur,

$\mathrm{E}$ is the EPIMODEL map from HIV and FHIV to AIDS;

$\varepsilon_{\mathrm{i}}$ and $\mu_{\mathrm{i}}$ are iid errors, each with zero mean;

$\beta_{0}, \beta_{1}, \lambda$, and $\alpha_{k}$ (the gamma function parameter in EPIMODEL, which we allow to vary among country groups) are parameters (or vectors of parameters) to be estimated;

The subscript $i$ refers to countries $(i=1, \ldots, T)$;

The subscript $k$ refers to country groups, which we define as the industrial countries of Europe, North America, and Oceania $(\mathrm{k}=1)$ and the developing countries of Asia, Africa, and Latin America $(k=2)$.

Equation (1) introduces the average annual increase in the cumulative prevalence of AIDS into a standard reduced form specification that relates the growth rate of real per capita GDP to a number of variables whose relationship to this growth rate is well established in the empirical literature on growth (see, as examples, Barro 1991; Bloom and Freeman 1986, 1988; Levine and Renelt 1992; Mankiw, Romer, and Weil 1992). The AIDS variable is expected to capture the effect on growth of a smaller, and possibly less productive, work force and of the diversion of social resources to the care for people with AIDS and the prevention of HIV transmission. The vector of control variables includes the initial level of per capita GDP; the lagged growth rate of real per capita GDP; and measures of the degree of openness of the economy, the stock of human capital, and the 
share of GDP devoted to public investment. In one specification, we include the rate of population growth, adjusted so that it does not reflect AIDS mortality. In another specification, we replace this variable with the average crude birth rate and the average crude death rate (also adjusted for AIDS mortality), which one would expect to have different influences on economic growth (see Bloom and Freeman 1988 and Coale 1986). The AIDS mortality adjustments are made so that the population variables do not capture any effects of AIDS on economic growth that might be operating through those variables.

Equation (3) allows for the possibility that the growth rate of GDP per capita influences the transmission of HIV. This mechanism could operate if commercially obtained sex is a normal economic good, positively associated with income and (in the long run) with income growth (see Over 1992). In addition, to the extent that income growth stimulates urbanization and movements of people and goods, either domestically or internationally, it may promote HIV transmission via the influence of increased anonymity on numbers of sex partners and the demand for commercial sex. Income growth could also depress HIV transmission by leading to increased longevity and improved health, especially to a lower rate of untreated sexually transmitted diseases, which are a powerful determinant of the probability of HIV infection (Over and Piot 1993). Higher levels of educational attainment, another positive correlate of income growth, may also reduce the risk of HIV transmission through increased access to information.

We begin by calculating nonlinear least squares (NLS) estimates of the parameters of equation (1) and $\alpha$. NLS is necessary because of the nonlinear relationship between GDP and HIV, which can be seen by substituting equation (2) into equation (1): 


$$
G D P_{i}=\beta_{0}+\beta_{1} E\left(\alpha_{k}, H I V_{i}, F H I V_{i}, P H I V\right)+X_{i} \lambda+\varepsilon_{i}
$$

We then account for possible simultaneity, using a nonlinear two stage least squares (NTSLS) procedure to estimate the parameters of equation (1) (see Amemiya 1985). Both the NLS and NTSLS estimates we compute allow $\alpha$ to vary in integer steps from 3 to 11 and to assume different values for developing and industrial countries. We do this by conducting grid searches over the eighty-one possible combinations of $\alpha$ and selecting the estimates that maximize the values of $R^{2}$ for each model and estimator. Amemiya (1985) proves the consistency of this estimator. [6] We also test for simultaneity by comparing the NLS estimates of the parameters of equation (1) with the NTSLS estimates.

\section{RESULTS}

Table 1 reports selected descriptive statistics for key variables used in our analysis. The statistics are reported for both the 51 countries in our sample and for a broader sample of 128 countries whose population and income data were reported in either the Human Development Report 1994 or the World Development Report 1994. For the 51-country sample, average cumulative AIDS prevalence from 1980 to 1992 is 4.9 per 1,000 adults (1.1 per 1,000 if weighted by adult population size in 1992), ranging from essentially zero in China to 39.6 in Zambia. HIV prevalence in 1992 averages 29.7 per 1,000 adults ( 6.0 per 1,000 if weighted by adult population size), ranging from a low of 0.01 in China to highs of 211.0 in Zambia and 191.0 in Uganda. 
The fifty-one countries in our sample include countries from all major regions and represent 69 percent of the total world population in 1992 . The population-weighted average per capita income of these countries was US\$5,406 in 1991 (after adjustment for purchasing power parity [PPP]), slightly less than the average for the broader comparison set. Income growth for the fifty-one countries averaged 3.86 percent from 1980 to 1992 (not using PPP-adjusted data), somewhat higher than the rate of 3.15 percent for the comparison set (both figures weighted by the size of the total population in 1992).

Table 2 reports NLS and NTSLS estimates of the parameters of equation (1). We computed the estimates in table 2 allowing $\alpha$ to vary and to assume different integer values for the developing and industrial countries. [7]

We first assess the impact of AIDS on income growth between 1980 and 1992. The year 1980 is roughly the point at which sizeable numbers of AIDS cases began to appear in a number of countries in the world. It is also a convenient starting point given the availability of data on key economic variables. Although narrowing the range of years diminishes the information content of the data with respect to long-term trends in economic growth and magnifies the relative importance of business cycle fluctuations and random shocks, we also focus on income growth between 1987 and 1992 because AIDS became widespread throughout the world during these years.

The first column of estimates in table 2 shows that income growth was lower in countries with larger increases in the cumulative prevalence of AIDS. The AIDS coefficient estimate is significant and sizeable, with each additional AIDS case per 1,000 persons per year being associated with a 0.86 percentage point reduction in the average annual rate of growth. The 1987-92 analysis 
exhibits a similar association. These results mainly reflect the fact that most of the seventeen African countries in our sample have both low growth rates and high AIDS prevalence relative to other countries in our data set.

The second and third columns in table 2 examine the association between AIDS prevalence and income growth controlling for various possible influences on income growth. Following the literature on empirical growth models, we include as controls the initial level of per capita income, a measure of "openness" (that is, the ratio of exports plus imports to GDP), the ratio of public sector defense and education expenditures to GDP, the 1970-80 annual growth rate of per capita income, average years of schooling in 1980 , and either the rate of population growth from 1980-92 or the average of the birth and death rates in 1980 and 1992 (see Barro 1991; Bloom and Freeman 1986, 1988; Levine and Renelt 1992; Mankiw, Romer, and Weil 1992). Both the population growth variable and the death rate variable are adjusted to remove the effects of AIDS mortality. This adjustment, which was derived using EPIMODEL with the final estimates of $\alpha$, increased the average rate of population growth from 1.82 to 1.85 percent per year and decreased the death rate from 10.47 to 10.17 per 1,000 population (based on the unweighted fifty-one country sample).

The most striking result in the second and third columns of estimates is that the introduction of controls drives the AIDS coefficient down substantially in (absolute) value and renders it insignificantly different from zero in both specifications. In other words, the raw negative association between economic growth and the change in AIDS prevalence is due to the fact that AIDS prevalence increased more in those countries with characteristics that are associated with slower growth, not apparently to AIDS itself having an independent negative influence on economic 
growth. The results for the period 1987-92, reported in the second panel of table 2, provide further confirmation of this basic result.

In analyses not reported in the tables, we also experimented with using HIV instead of AIDS prevalence, including cumulative AIDS prevalence as of 1980 or 1987 (depending on whether the dependent variable measures growth from 1980 or 1987), introducing controls for region, using population growth from 1970-80 instead of 1980-92, separating government expenditures on education and defense, and setting $\alpha$ equal to Chin and Lwanga's preferred value of 5 for all countries. Our central finding about the epidemic's insignificant effect on income growth was not altered in any of these analyses. We also estimated a specification that is quadratic in the change in cumulative AIDS prevalence, but found no evidence of a statistically significant departure from linearity.

Note also that the estimates of the coefficients of the control variables in specification (2) are generally consistent with estimates reported elsewhere in the empirical growth literature. For example, because the rate of growth of per capita income is negatively related to the past level of per capita income, the estimates suggest convergence in levels of income per capita. The estimates also suggest that both openness and government investment promote economic growth and that rapid population growth or a high birth rate depress economic growth. However, as estimates of the schooling coefficient are consistently small and insignificantly different from zero, the estimates do not support the hypothesis that growth is promoted by having a higher initial stock of human capital. In keeping with the findings of Bloom and Freeman (1988) and Coale (1986), the estimates reveal a positive but statistically insignificant association between the adjusted death rate and growth. 
The fourth and fifth specifications in table 2 report NTSLS estimates of the effect of AIDS prevalence on average income growth. We instrument both the annual average increase in cumulative AIDS prevalence and the adjusted rate of population growth (or the birth and adjusted death rates) with the following variables in both the 1980-92 and 1987-92 analyses: 1989 percentages of the population that are Christian and Muslim, life expectancy in 1980, urbanization in 1980 , the growth rate of the urban population from 1970 to 1980 , the physician-to-population ratio in 1980 , the ratio of international tourists to population in 1980 , the adult literacy rate in 1980 , and FHIV. [8]

In principle, the NTSLS estimates account for the possible reciprocal influence of income growth on HIV transmission and AIDS. However, accounting for possible simultaneity has remarkably little effect on the coefficient estimates, with the NTSLS estimate of the AIDS coefficient remaining statistically insignificant in all analyses. Indeed, specification tests are unable to reject the null hypothesis of no simultaneity for any of the comparable specifications in table 2. [9]

Although none of the estimated coefficients of the change in cumulative AIDS prevalence variables reported in specifications (2) through (5) in table 2 are significantly different from zero, it is instructive to assess their magnitude, especially in relation to the effects estimated in previous literature (for which there are no standard errors). For example, projections constructed using EPIMODEL indicate that cumulative AIDS prevalence in Tanzania will increase by 5.29 per 1,000 adults per year between 1991 and 2010. Using this figure, the 1980-92 NTSLS specification in table 2 suggests that projected changes in cumulative AIDS prevalence in Tanzania will depress its annual growth rate of income per capita by 0.21 percentage points $(=5.29 \times-0.04)$. Note, however, the 
considerable variability, from -0.21 to +1.01 , in the growth effect of AIDS across the 1980-92 specifications in table 2. Although the "best estimates" of the effect of AIDS on growth rates of income per capita reported in Cuddington $(1992,1993)$ and Over $(1992)$ tend to fall below this range, their results rest upon the relatively high AIDS projections made by the World Bank in the late 1980s (see Bulatao 1990; Over 1992). [10]

\section{COMPARING AIDS WITH OTHER EPIDEMICS}

Additional perspective on the foregoing results may be gained by comparing them with the economic impacts of other epidemics that claimed many lives. In this connection, the AIDS epidemic, which has no effect on nonlabor factors of production and no debilitating effect on the productivity of uninfected people, is most naturally compared with the Black Death that swept Europe during the Middle Ages and with the 1918-19 influenza epidemic in India.

The Black Death was a combined epidemic of the bubonic and pneumonic plagues that spread throughout western Europe during 1348-1350 (although we include later plague epidemics in our analysis as well). During that period, an estimated 24 percent of western Europe's population died, more than two-thirds of which represented excess mortality (Russell 1948). The two types of plague, which are different forms of the same bacterial infection, were transmitted from rodent to human populations by fleas. The bubonic plague is not infectious among humans, although it can lead to the pneumonic plague as a complication, which is infectious among humans and was nearly always fatal before antibiotics. Overall, the fatality rate for both types of plague cases during the Black Death is believed to have reached 90 percent (Bres 1986). Some evidence indicates that older 
individuals were disproportionately more susceptible to the plague and that the poor were more exposed to infection because of unfavorable sanitary conditions. Nonetheless, there is little reason to believe that either the age or income differentials were large (Hirshleifer 1987; Russell 1948).

Although data on per capita income or output are not available, medieval historians report a rapid rise in various wage indicators in both England and France during the course of, and immediately following, the Black Death (see Hirshleifer 1987; Robbins 1928; Russell 1948; Slicher van Bath 1963). Whether these increases reflect mainly a shrinking supply of labor (see Hirshleifer 1987), an upward long-run trend in real wages, or a highly inelastic demand for labor in the very short run is, however, unclear. [11]

To help interpret the reported wage increases, we examine annual average percentage changes in real wages for unskilled British agricultural laborers working on the estates of the bishops of Winchester during six subperiods during 1310 to 1449 , that is, $1310-29,1330-69,1370-89,1390-$ $1409,1410-29$, and 1430-49. The wage data are deflated by the price of wheat. We measure the association between the real wage changes and changes in the population of England during the corresponding subperiods. The population changes reflect the effects of the major plagues that occurred in 1348-50, 1360-61,1369, and 1374, which resulted in estimated excess mortality of 16.6 percent, 12.7 percent, 10.0 percent, and 8.6 percent, respectively (see Hirshleifer 1987, table $2.2, \mathrm{p}$ 100 , which is drawn from Russell 1948, p. 263).

The first row of figures in table 3 reports estimates of a simple regression of the growth rate of (wheat-price deflated) wages on population growth. Although the positive intercept indicates long-term real wage growth, the coefficient of the population growth variable is small and 
insignificantly different from zero. Thus, one cannot reject the null hypothesis that real wages did not exhibit a differential rate of growth during periods of the major medieval plagues in England.

Data reported in Robbins (1928) permit some analysis of the effect of the plague on wages in France. Two series of nominal daily wages are available, for workers nourri (fed) and workers non-nourri (not fed), for quarter-century periods from 1301 to 1500 . Deflating these series by the price of poultry converts them to real wage series. Regressing the quarter-century changes in each deflated series on a constant and a dummy variable taking the value one during 1338-62 and 1363-87 -- major plague periods in France -- provides evidence of an insignificant positive trend in both wage series, with a small and statistically insignificant increase during the major plague periods.

Although these wage change analyses are admittedly crude because of severe data limitations, they nonetheless provide no evidence that real wages departed significantly from their long-term trend during periods of great plague mortality in England and France.

The influenza epidemic of 1918-19 provides another opportunity to examine the effect of a sharp increase in mortality on income. In India, where the worldwide epidemic was most severe, influenza claimed an estimated 20 million lives, or 6.2 percent of India's total population and 8.3 percent of the working age population in agriculture (Schultz 1983). Mortality rates among the working age population in agriculture varied from 2 to 15 percent across provinces. Data on death rates in the 1918-19 cropping season and on changes in acreage sown and the size of the agricultural population from the 1916-17 season to the 1919-20 season -- which were comparable in terms of climatic conditions -- are reported in Schultz (1983) and Sen (1967), who debated their use in testing the surplus labor hypothesis. 
The Indian data permit us to examine the effect of a sharp and unanticipated decline in population on output per capita. The data reveal declines in acreage sown per capita in seven of thirteen provinces between 1916-17 and 1919-20. However, the regression of acreage sown per capita on the estimated change in the agricultural population provides no evidence that the decline in acreage sown was significantly greater in provinces that experienced sharper population declines. These cross-provincial results are thus qualitatively similar to those on the wage effects of the Black Death in Europe.

\section{SUMMARY AND CONCLUSION}

The results of our cross-country analysis provide little support for the widespread claim that the AIDS epidemic will slow the growth rate of income per capita. Although the epidemic is already quite advanced in a number of countries, after controlling for standard influences on growth (and possible simultaneity), we find no evidence that the economies of those countries grew at a significantly slower pace between 1980 (1987) and the early 1990s than those of other countries in which changes in the cumulative prevalence of AIDS was lower. Although our point estimates vary quite widely from negative to positive across specifications, nearly all of the estimates fall well below their estimated standard errors. This finding is consistent with several crude analyses we performed of the impact on the growth rates of either real wages or output per capita of two other major epidemics: the Black Death during the Middle Ages and the influenza epidemic of 1918-19. Our findings suggest that there is more flash than substance to the claim that AIDS impedes national economic growth. Further research aimed at explaining this finding in terms of labor supply 
and demand elasticities, relative shifts in labor supply and demand caused by AIDS morbidity and mortality, the emerging link between AIDS and poverty, and economic and institutional adjustments that dampen the adverse economic impacts of the epidemic would be extremely useful. Further work is also needed to assess whether our main conclusion applies to the impact of AIDS on the broader concept of economic development. Along these lines, Bloom, and others (1995) suggest that it does not, mainly because AIDS has a large negative impact on life expectancy, a major component of the UNDP's human development index on which their analysis focuses. Thus, the AIDS epidemic may well prove to have significant implications for development even though its implications for per capita income are not significant.

Although we find little support for the often made argument that HIV and AIDS prevention and control programs will yield benefits via a higher rate of income growth, our study does not deny the existence of other benefits. Indeed, much ongoing research suggests that the most serious economic consequences of the AIDS epidemic are to be found in particular industrial and occupational sectors, in particular geographic regions, and among particular demographic groups, especially people living with AIDS and their families, women, children, the poor, and other marginalized groups, such as homosexuals and drug users (Basu, Gupta, and Krishna 1995; Bloom and others 1995; The Panos Institute 1992; Pitayanon, Kongsin, and Janjareon 1994). These topics appear to be the most promising areas for further research, along with greater application of cost-benefit and cost-effectiveness analysis to programs and policies that address the care of persons living with AIDS and the prevention of further HIV transmission. 


\section{Notes}

1. As another example, Mann, Tarantola, and Netter (1992, p. 195) write that "the adverse impacts of the AIDS epidemic will ... reduce the potential for economic growth. AIDS is distinct and ... its impact can be expected to be quite severe." Similarly, Cohen $(1993$, p. 32) concludes that "the economic and social costs of HIV are truly colossal. The epidemic, if unchecked, could transform the developmental performance of many countries." Elsewhere, in The Panos Institute (1992, p. 116), the authors claim that "HIV/AIDS has the capacity to seriously undermine the development prospects of many nations."

2. This result refers to the "average" sub-Saharan country. If the simulations are confined to the ten African countries with the most advanced epidemics, the average negative effect on per capita income growth is 0.6 percent per year.

3. However, note that Cuddington (1992) finds little evidence that his results for Tanzania are sensitive to the presence of surplus labor.

4. Chin and Lwanga (1991) report that $\alpha=5$ provides a good fit to time series data on AIDS cases in countries with reasonably accurate reporting systems.

5. Gail and Brookmeyer (1988) show that this pattern of progression is well approximated by a Weibull distribution

6. Although the model technically treats the ADS data as nonstochastic, the two stage least squares estimation procedure will also correct for classical error in the measurement of AIDS.

7. We also estimate the parameters of equation (1) with AIDS data constructed using Chin and Lwanga's preferred value of $\alpha=5$ for all countries. As the estimates were qualitatively the same in all cases, they are not separately reported

8. The results were not substantially different when FHIV was excluded from the list of instruments.

9. The test statistics for a comparison of specifications (2) and (4) and (3) and (5) in panel 1 are 1.22 and 0.49 , respectively. For panel 2 the corresponding test statistics are 7.10 and 0.46 . Under the null hypothesis of no simultaneity, these statistics have chi square distributions with 8 and 9 degrees of freedom, respectively. The critical values for these statistics at the 5 percent level are 15.5 and 16.9 .

10. For example, Bulatao's projections of cumulative AIDS prevalence for Tanzania increase at an annual rate of 10 per 1,000 adults from 1991 to 2010 . This figure is nearly double the corresponding rate of increase we project using EPIMODEL with more recent data on HIV prevalence.

11. Indeed, one account of the sharply higher wages describes them as "panic or compulsion" rates of pay (Robbins 1928, p. 463). 


\section{References}

Ahituv, Avner, V. Joseph Hotz, and Tomas Philipson. 1993. "Will the AIDS Epidemic be Self-Limiting? Evidence on the Responsiveness of the Demand for Condoms to the Prevalence of AIDS." Discussion Paper No. 93-3. Chicago: University of Chicago, Population Research Center.

Amemiya, Takeshi. 1985. Advanced Econometrics. Cambridge, MA: Harvard University Press.

Barnett, Tony, and Piers Blaikie. 1992. AIDS in Africa: Its Present and Future Impact. London: The Guilford Press.

Baron, Raymond. 1989. Travel and Tourism Data. London: Euromonitor Publications.

Barro, Robert. 1991. "Economic Growth in a Cross Section of Countries." Quarterly Journal of Economics 106(2):407-45.

Basu, Alaka M., Devendra B. Gupta, and Geetanjali Krishna. 1995. "The Household Impact of Adult Morbidity and Mortality: Some Implications of the Potential Epidemic of AIDS in India." Draft. New Delhi, India: Institute of Economic Growth.

Bloom, David, and Geoffrey Carliner. 1988. "The Economic Impacts of AIDS in the United States." Science 239(4840):604-10.

Bloom, David, and Richard Freeman. 1986. "The Effects of Rapid Population Growth on Labor Supply and Employment in Developing Countries." Population and Development Review 12(3):381-414.

1988. "Economic Development and the Timing and Components of Population Growth." Journal of Policy Modeling 10(1):57-82.

Bloom, David, and Sherry Glied. 1989. "The Evolution of AIDS Economic Research." Health Policy 11(2): 187-96.

1992. "Projecting the Numbers of New AIDS Cases in the United States." International Journal of Forecasting 8(3):339-66.

1993. "Who is Bearing the Cost of the AIDS Epidemic in Asia." In David Bloom, and Joyce Lyons, eds., Economic Implications of AIDS in Asia. New Delhi, India: United Nations Development Programme.

Bloom, David, and Joyce Lyons, eds. 1993. Economic Implications of AIDS in Asia. New Delhi, India: United Nations Development Programme. 
Bloom, David, and Ajay Mahal. 1995. "The Economic Implications of AIDS in Asia." Draft. New York: Columbia University, Department of Economics.

Bloom, David, Lene Christiansen, Amala de Silva, Soma de Silva, Malsiri Dias, Saroj Jayasinghe, Swarna Jayaweera, Ajay Mahal, Soma Mahawewa, Thana Sanmugam, and Gunatillake Tantrigama. 1995. "The Economic Implications of AIDS in Sri Lanka." Colombo, Sri Lanka: United Nations Development Programme.

Bloom, David, Neil Bennett, Ajay Mahal, and Waseem Noor. 1995. "The Impact of AIDS on Human Development." Draft. New York: Columbia University, Department of Economics.

Bres, P. 1986. Public Health Action in Emergencies Caused By Epidemics. Geneva: World Health Organization.

Brown, Tim, Chirapun Gullaprawit, Werasit Sittitrai, Sombat Thanprasertsuk, and Aphichat Chamratrithirong. 1994. "Projections for HIV in Thailand 1987-2005: An Application of EPIMODEL." Draft. Bangkok, Thailand: National Economic and Social Development Board Working Group.

Bulatao, Rodolfo. 1990. "The Demographic Impact of AIDS in Tanzania." Background paper prepared for the Tanzania AIDS Assessment and Planning Study. Washington, D.C.: World Bank.

Chin, James. 1990. "Current and Future Dimensions of the HIV/AIDS Pandemic in Women and Children." The Lancet 336:221-24.

1995. "Estimation and Projection of HIV Infections and AIDS Cases." Draft. Berkley, CA: University of California, School of Public Health.

1994. "A Beginner's Guide for Understanding and Using EPIMODEL - Version 2." Draft. Berkley, CA: University of California, School of Public Health.

Chin, James, and S. K. Lwanga. 1991. "Estimation and Projection of Adult AIDS Cases: A Simple Epidemiological Model." Bulletin of the World Health Organization 69:399-406.

Coale, Ansley. 1986. "Population Trends and Economics Development." In Jane Menken, ed. World Population and U.S. Policy. New York : W. W. Norton \& Company, Inc.

Cohen, Desmond. 1993. "The Economic Impact of the HIV Epidemic." Working Paper. New York: United Nations Development Programme, HIV and Development Programme

Cuddington, John. 1992. "The Macroeconomic Impact of AIDS in a Dualistic, Labor-Surplus 
Economy with an Application to Tanzania." Working Paper No. 92-12. Washington, D.C.: Georgetown University, Department of Economics.

1993. "Modeling the Macroeconomic Effects of AIDS, with an Application to Tanzania." The World Bank Economic Review 7(2):173-89.

Cuddington, John, and John Hancock. 1994. "Assessing the Impact of AIDS on the Growth Path of the Malawian Economy." Journal of Development Economics 4(3):363-68.

Gail, Mitchell, and Ronald Brookmeyer. 1988. "Methods for Projecting the Course of the Acquired Immunodeficiency Syndrome Epidemic." Journal of the National Cancer Institute 80(12):900-12.

Griffin, Charles. 1990. Health Financing in Asia. Report No. 8553-ASI. Washington, D.C.: World Bank.

Hellinger, Fred. 1993. "The Lifetime Cost of Treating a Person with HIV." Journal of the American Medical Association 270(4):474-78.

Hirshleifer, Jack. 1987. Economic Behavior in Adversity. Chicago: University of Chicago Press.

Kambou, Gerard, Shantayanan Devarajan, and Mead Over. 1992. "The Economic Impact of AIDS in an African Country: Simulations with a Computable General Equilibrium Model of Cameroon." Journal of African Economies 1(1):109-30.

Kraas-Schneider, Frauke. 1989. Bevolkerungsgruppen und Minoritaten. Handbuch der ethnischen, sprachlichen und religiosen bevolkerungsgruppen der Welt. Stuttgart: Franz Steiner Verlag.

Kremer, Michael. 1995. "Integrating Behavioral Choice into Epidemiological Models of AIDS." Draft. Cambridge, MA: Massachussetts Institute of Technology, Department of Economics.

Levine, Ross, and David Renelt. 1992. "A Sensitivity Analysis of Cross-Country Growth Regressions." American Economic Review 82(September):942- 63.

Lyons, Joyce. 1993. "Introduction." In David Bloom and Joyce Lyons, eds. Economic Implications of AIDS in Asia. New Delhi, India: United Nations Development Programme

Mankiw, Gregory, David Romer, and David Weil. 1992. “A Contribution to the Empirics of Economic Growth.” Quarterly Journal of Economics 107(2):407-37.

Mann, Jonathan, Daniel Tarantola, and Thomas Netter. 1992. AIDS in the World. Cambridge, MA: Harvard University Press. 
Merson, Michael. 1992. "AIDS in Asia and the Pacific: The Reality, the Opportunity, and the Challenge." Keynote address at the Second International Congress on AIDS in Asia and the Pacific, New Delhi, India, November.

Over, Mead. 1992. “The Macroeconomic Impact of AIDS in Sub-Saharan Africa." Technical Working Paper No.3. Washington, D.C.: World Bank, Africa Technical Department, Population, Health, and Nutrition Division.

Over, Mead, and Peter Piot. 1993. "HIV Infection and Sexually Transmitted Diseases." In Dean Jamison, W. Henry Mosley, Anthony Measham, and Jose Bobadilla, eds., Disease Control Priorities in Developing Countries. Washington, D.C.: Oxford University Press.

Panos Institute, The. 1992. The Hidden Cost of AIDS: The Challenge of HIV to Development. London: Panos Publications.

PCGlobe, Inc. The PCGlobe Database, Tempe, AZ.

Peterson, Georg, and Rabin Sarda. 1995. "The HIV and AIDS Epidemic in the Western Pacific." Draft. Manila, Philippines: World Health Organization, Regional Office for the Western Pacific.

Philipson, Tomas, and Richard Posner. 1993. Private Choices and Public Health: The AIDS Epidemic in an Economic Perspective. Cambridge, MA: Harvard University Press.

Pitayanon, Sumalee, Sukhontha Kongsin, and Wattana Janjareon. 1994. Economic Impact of HIV/ AIDS Mortality on Households in Thailand. Research report presented at the Asian Development Bank/ United Nations Development Programme Finalization Meeting on Economic Implications of HIV/AIDS, Manila, Philippines, August 2-4.

Robbins, Helen. 1928. "A Comparison of the Effects of the Black Death on the Economic Organization of France and England." Journal of Political Economy 36(August):447-79.

Rojanapithayakorn, W. 1994. "The One Hundred Percent Condom Programme in Thailand: An Update." Abstract No. 478C, The Tenth International Conference on AIDS, Yokohama, Japan, August 7-12.

Russell, Josiah. 1948. British Medieval Population. Albuquerque, New Mexico: The University of New Mexico Press.

Schultz, Theodore. 1983. Transforming Traditional Agriculture, 2nd ed. Chicago: University of Chicago Press.

Sen, Amartya. 1967. "Surplus Labor in India: A Critique of Schultz's Statistical Test." Economic 
Journal (March): 154-61

Sisk, Jane. 1987. "The Costs of AIDS: A Review of the Estimates." Health Affairs 6(2):5-21.

Slicher van Bath, B. H. 1963. The Agrarian History of Western Europe. A.D. 500-1850.

London: Edward Arnold Publishers.

Snell, J., E. Supran, and H. Tamashiro. 1992. "WHO International Quality Assessment Scheme for HIV Antibody Testing: Results From the Second Distribution of Sera." Bulletin of the World Health Organization 70(5):605-13.

Summers, Robert, and Alan Heston. 1991. "The Penn World Table (Mark 5): An Expanded Set of International Comparisons." Quarterly Journal of Economics (May):327-68.

UN (United Nations). 1993. World Population Prospects. New York: United Nations, Department for Economic and Social Information and Policy Analysis.

UNDP (United Nations Development Programme). 1992. “The HIV Epidemic as a Development Issue." Pamphlet. New York: United Nations Development Programme.

1994. Human Development Report 1994. New York: Oxford University Press.

U.S. Bureau of the Census. 1993. HIV/AIDS Surveillance Database. Washington, D.C.: Center for International Research

1994. The Impact of HIV/AIDS on World Population Washington, D.C.: Government Printing Office.

Viravaidya, Mechai, Stasia Obremsky, and Charles Myers. 1993. "The Economic Impact of AIDS in Thailand." In David Bloom and Joyce Lyons, eds., Economic Implications of AIDS in Asia. New Delhi, India: United Nations Development Programme.

World Bank. 1992. Tanzania: AIDS Assessment and Planning Study. Washington, D.C.

1993a. The World Development Report. Washington, D.C.: Oxford University Press. 1993b. Social Indicators of Development Database. Washington, D.C.

1994. World Tables 1993. Washington, D.C.: Oxford University Press.

WHO (World Health Organization). 1992. "AIDS/HIV Infection in Southeast Asia." New Delhi, India: Regional Office for Southeast Asia. 
1994a. The HIV/AIDS Pandemic: 1994 Overview. Geneva: WHO, Global Programme on AIDS.

1994b. The Current Global Situation of the HIV/AIDS Pandemic. Geneva: WHO, Global Programme on AIDS.

1995. The Current Global Situation of the HIV/AIDS Epidemic. Geneva: WHO, Global Programme on AIDS.

WorldAIDS. 1993. DataFile 1993. London: Panos Publishers. 
Table 1. Descriptive statistics on selected Variables

\begin{tabular}{|c|c|c|c|c|}
\hline \multirow[b]{2}{*}{ Variable } & \multicolumn{2}{|c|}{ Fifty-one country sample ${ }^{a}$} & \multicolumn{2}{|c|}{$\begin{array}{c}\text { Comparison sample of } \\
128 \text { countries }\end{array}$} \\
\hline & Average & Standard deviation & Average & Standard deviation \\
\hline $\begin{array}{l}\text { GDP per capita, } 1991 \text { (\$US) } \\
\text { (population weighted) }\end{array}$ & 5,406 & 6,708 & 5,501 & 6,450 \\
\hline $\begin{array}{l}\text { Average annual rate of } \\
\text { growth of per capita GDP, } \\
1980-92 \\
\text { (population weighted) }\end{array}$ & 3.86 & 2.95 & 3.15 & 3.11 \\
\hline $\begin{array}{l}\text { HIV prevalence per } \\
1,000 \text { adults, } 1992 \\
\text { Weighted } \\
\text { Unweighted }\end{array}$ & $\begin{array}{r}6.00 \\
29.74\end{array}$ & $\begin{array}{l}23.28 \\
51.49\end{array}$ & $\begin{array}{l}\text { n.a. } \\
\text { n.a. }\end{array}$ & $\begin{array}{l}\text { n.a. } \\
\text { n.a. }\end{array}$ \\
\hline $\begin{array}{l}\text { Cumulative AIDS cases } \\
\text { per 1,000 adults, 1980-92 } \\
\text { Weighted } \\
\text { Unweighted }\end{array}$ & $\begin{array}{l}1.08 \\
4.90\end{array}$ & $\begin{array}{l}4.35 \\
9.06\end{array}$ & $\begin{array}{l}\text { n.a. } \\
\text { n.a. }\end{array}$ & $\begin{array}{l}\text { n.a. } \\
\text { n.a. }\end{array}$ \\
\hline $\begin{array}{l}\text { Cumulative AIDS cases } \\
\text { per } 1000 \text { adults, } 1987-92 \\
\text { Weighted } \\
\text { Unweighted }\end{array}$ & $\begin{array}{l}0.92 \\
4.24\end{array}$ & $\begin{array}{l}3.66 \\
7.72\end{array}$ & $\begin{array}{l}\text { n.a. } \\
\text { n.a. }\end{array}$ & $\begin{array}{l}\text { n.a. } \\
\text { n.a. }\end{array}$ \\
\hline
\end{tabular}




\section{Notes:}

a. Our sample includes fifty-one countries: Africa: Burkina Faso, Burundi, Central African Republic, Congo, Cote d'Ivoire Gabon, Gambia, Ghana, Kenya, Malawi, Mali, Nigeria, Tanzania, Uganda, Zaire, Zambia, Zimbabwe; Asia: Bangladesh, China, Hong Kong, India, Indonesia, Republic of Korea, Myanmar, Nepal, Philippines, Singapore, Sri Lanka, Thailand; Latin America: Brazil, Honduras; Europe: Austria, Belgium, Denmark, Finland, France, Germany, Greece, Ireland, Israel, Italy, Netherlands, Norway, Spain, Portugal, Sweden, Switzerland, United Kingdom; North America: United States, Canada; Oceania: Australia.

b. These are purchasing-power parity adjusted estimates of GDP per capita as reported in Human Development Report 1994 (UNDP 1994).

c. Adult population sizes are used in constructing the weighted estimates. 


\section{The Impact of AIDS on the Growth Rate of Real GDP Pex Capita,}

1980-92 and 1987-92

\begin{tabular}{|c|c|c|c|c|c|c|c|c|c|c|}
\hline & \multicolumn{5}{|c|}{$1980-92$} & \multicolumn{5}{|c|}{$1987-92$} \\
\hline & $\begin{array}{l}\text { NLS } \\
(1)\end{array}$ & $\begin{array}{l}\text { NLS } \\
(2)\end{array}$ & $\begin{array}{c}\text { NLS } \\
(3) \\
\end{array}$ & $\begin{array}{l}\text { NTSLS } \\
\text { (4) }\end{array}$ & $\begin{array}{l}\text { NTSLS } \\
(5)\end{array}$ & $\begin{array}{l}\text { NLS } \\
(1)\end{array}$ & $\begin{array}{l}\text { NLS } \\
(2)\end{array}$ & $\begin{array}{l}\text { NLS } \\
\text { (3) }\end{array}$ & $\begin{array}{l}\text { NTSLS } \\
(4)\end{array}$ & $\begin{array}{c}\text { NTSLS } \\
(5)\end{array}$ \\
\hline Constant & $\begin{array}{l}1.96 \\
(0.36)\end{array}$ & $\begin{array}{l}3.13 \\
(1.19)\end{array}$ & $\begin{array}{l}6.89 \\
(1.93)\end{array}$ & $\begin{array}{l}3.41 \\
(1.23)\end{array}$ & $\begin{array}{l}7.22 \\
(2.25)\end{array}$ & $\begin{array}{l}2.18 \\
(0.39)\end{array}$ & $\begin{array}{l}5.08 \\
(1.10)\end{array}$ & $\begin{array}{l}7.44 \\
(2.50)\end{array}$ & $\begin{array}{l}4.67 \\
(1.18)\end{array}$ & $\begin{array}{l}7.61 \\
(2.52)\end{array}$ \\
\hline $\begin{array}{l}\text { Average annual change } \\
\text { in cumulative AIDS cases } \\
\text { per } 1000 \text { adults }\end{array}$ & $\begin{array}{l}-0.86 \\
(0.19)\end{array}$ & $\begin{array}{l}-0.02 \\
(0.22)\end{array}$ & $\begin{array}{c}0.19 \\
(0.28)\end{array}$ & $\begin{array}{l}-0.04 \\
(0.36)\end{array}$ & $\begin{array}{c}0.15 \\
(0.40)\end{array}$ & $\begin{array}{l}-0.48 \\
(0.13)\end{array}$ & $\begin{array}{l}-0.19 \\
(0.17)\end{array}$ & $\begin{array}{l}-0.04 \\
(0.22)\end{array}$ & $\begin{array}{l}-0.07 \\
(0.21)\end{array}$ & $\begin{array}{l}0.18 \\
(0.25)\end{array}$ \\
\hline $\begin{array}{l}\text { GDP per capita } \\
\text { (in } \$ 000 \mathrm{~s})\end{array}$ & & $\begin{array}{l}-0.21 \\
(0.13)\end{array}$ & $\begin{array}{l}-0.30 \\
(0.15)\end{array}$ & $\begin{array}{l}-0.21 \\
(0.13)\end{array}$ & $\begin{array}{l}-0.37 \\
(0.19)\end{array}$ & & $\begin{array}{l}-0.29 \\
(0.12)\end{array}$ & $\begin{array}{l}-0.36 \\
(0.14)\end{array}$ & $\begin{array}{l}-0.29 \\
(0.13)\end{array}$ & $\begin{array}{l}-0.43 \\
(0.18)\end{array}$ \\
\hline $\begin{array}{l}\text { Rate of growth of } \\
\text { real GDP per capita (lagged) }\end{array}$ & & $\begin{array}{l}0.29 \\
(0.15)\end{array}$ & $\begin{array}{l}0.22 \\
(0.16)\end{array}$ & $\begin{array}{l}0.28 \\
(0.16)\end{array}$ & $\begin{array}{l}0.20 \\
(0.19)\end{array}$ & & $\begin{array}{l}0.07 \\
(0.16)\end{array}$ & $\begin{array}{l}0.18 \\
(0.15)\end{array}$ & $\begin{array}{l}0.13 \\
(0.20)\end{array}$ & $\begin{array}{c}0.23 \\
(0.18)\end{array}$ \\
\hline $\begin{array}{l}\text { Government expenditures on } \\
\text { education and defense as } \\
\text { a proportion of GDP }\end{array}$ & & $\begin{array}{l}0.34 \\
(0.10)\end{array}$ & $\begin{array}{c}0.27 \\
(0.10)\end{array}$ & $\begin{array}{l}0.34 \\
(0.10)\end{array}$ & $\begin{array}{l}0.29 \\
(0.10)\end{array}$ & & $\begin{array}{l}0.22 \\
(0.10)\end{array}$ & $\begin{array}{c}0.13 \\
(0.11)\end{array}$ & $\begin{array}{c}0.18 \\
(0.10)\end{array}$ & $\begin{array}{c}0.12 \\
(0.11)\end{array}$ \\
\hline $\begin{array}{l}\text { Average schooling } \\
\text { in } 1980\end{array}$ & & $\begin{array}{c}0.05 \\
(0.18)\end{array}$ & $\begin{array}{l}-0.003 \\
(0.193)\end{array}$ & $\begin{array}{c}0.03 \\
(0.18)\end{array}$ & $\begin{array}{c}0.01 \\
(0.22)\end{array}$ & & $\begin{array}{c}0.002 \\
(0.164)\end{array}$ & $\begin{array}{c}-0.02 \\
(0.21)\end{array}$ & $\begin{array}{c}0.04 \\
(0.18)\end{array}$ & $\begin{array}{c}0.03 \\
(0.24)\end{array}$ \\
\hline $\begin{array}{l}\text { Ratio of imports plus } \\
\text { exports to GDP }\end{array}$ & & $\begin{array}{c}0.88 \\
(0.37)\end{array}$ & $\begin{array}{c}0.30 \\
(0.33)\end{array}$ & $\begin{array}{c}0.91 \\
(0.36)\end{array}$ & $\begin{array}{c}0.29 \\
(0.10)\end{array}$ & & $\begin{array}{c}1.74 \\
(0.52)\end{array}$ & $\begin{array}{c}0.99 \\
(0.57)\end{array}$ & $\begin{array}{c}1.69 \\
(0.56)\end{array}$ & $\begin{array}{c}1.05 \\
(0.65)\end{array}$ \\
\hline $\begin{array}{l}\text { Average annual rate of } \\
\text { population growth } \\
\text { (AIDS adjusted) } \\
\text { per } 1000 \text { population }\end{array}$ & & $\begin{array}{l}-0.19 \\
(0.04)\end{array}$ & & $\begin{array}{l}-0.20 \\
(0.04)\end{array}$ & & & $\begin{array}{l}-0.20 \\
(0.04)\end{array}$ & & $\begin{array}{l}-0.19 \\
(0.06)\end{array}$ & \\
\hline $\begin{array}{l}\text { Average birth rate } \\
\text { per } 1000 \text { population }\end{array}$ & & & $\begin{array}{l}-0.26 \\
(0.06)\end{array}$ & & $\begin{array}{l}-0.30 \\
(0.09)\end{array}$ & & & $\begin{array}{l}-0.26 \\
(0.07)\end{array}$ & & $\begin{array}{l}-0.30 \\
(0.08)\end{array}$ \\
\hline $\begin{array}{l}\text { Average death rate } \\
\text { (AIDS adjusted) } \\
\text { per } 1000 \text { population }\end{array}$ & & & $\begin{array}{c}0.06 \\
(0.07)\end{array}$ & & $\begin{array}{c}0.16 \\
(0.14)\end{array}$ & & & $\begin{array}{c}0.13 \\
(0.10)\end{array}$ & & $\begin{array}{c}0.20 \\
(0.17)\end{array}$ \\
\hline$\alpha$ (industrial countries) & 3 & 9 & 9 & 9 & 9 & 3 & 9 & 9 & 9 & 9 \\
\hline$\alpha$ (developing countries) & 3 & 3 & 3 & 3 & 3 & 3 & 3 & 3 & 3 & 3 \\
\hline $\begin{array}{l}R^{2} \\
R^{2} \text { (first stage regression) }\end{array}$ & 0.17 & 0.60 & 0.55 & $\begin{array}{l}0.60 \\
0.73\end{array}$ & $\begin{array}{l}0.55 \\
0.73\end{array}$ & 0.18 & 0.52 & 0.47 & $\begin{array}{l}0.51 \\
0.64\end{array}$ & $\begin{array}{l}0.45 \\
0.64\end{array}$ \\
\hline
\end{tabular}




\section{Notes:}

Heteroskedasticity-consistent (White) standard errors are reported in parentheses below the coefficient estimates.

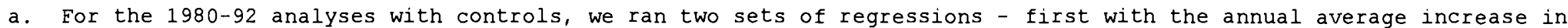
the cumulative number of AIDS cases (per 1,000 adults) over the period 1980 to 1992 , the level of per capita GDP in 1980, the ratio of imports plus exports to GDP in 1980, the rate of growth of per capita GDP during $1970-80$, and the

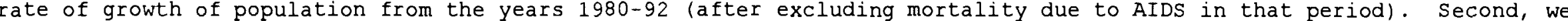
replaced the rate of population growth variable by birth rates and death rates (per 1,000 population) during $1980-92$ (death rates were adjusted to exclude mortality due to AIDS). For the $1987-92$ analyses, we used the annual average

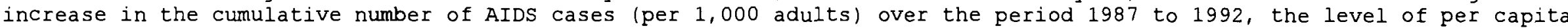

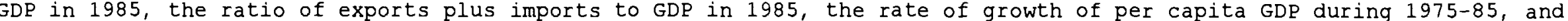
adjusted rates of population growth, birth rates and adjusted death rates just as for the $1980-92$ analysis.

b. For the two-stage least squares regressions reported here, the following variables served as instruments:

(i) For the regression of per capita GDP 1980-92:

Percentage of population christian, percentage Muslim, life expectancy at birth (1980), number of doctors per 1 , 000 population (1980), number of tourists per 1,000 population (1980), growth rate of urban population from 1970-80, percentage of population urban (1980), per capita income 1980, rate of growth of per capita income 1970-80, FHIV,

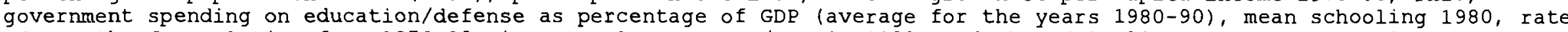
of growth of population from 1970-80, imports plus exports/GDP in 1980, and the adult literacy rate for 1980.

(ii) For the regression of per capita GDP 1987-92:

Percentage of population Christian, percentage Muslim, life expectancy at birth (1980), number of doctors per 1 , 000 population (1980), number of tourists per 1,000 population (1980), growth rate of urban population from 1970-80, percentage of population urban (1980), per capita income 1985, rate of growth of per capita GDP 1975-85, FHIV,

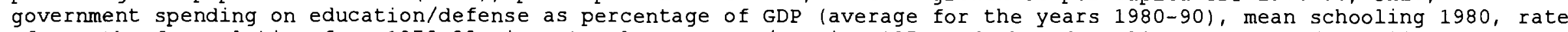
of growth of population from 1970-80, imports plus exports/GDP in 1985, and the adult literacy rate for 1980 . 
Table 3. Economic Impacts of Other Epidemics

\begin{tabular}{|c|c|c|c|c|}
\hline Dependent variables & Constant & $\begin{array}{l}\text { Regressors } \\
\text { Rate of growth } \\
\text { of population }\end{array}$ & $\begin{array}{l}\text { Indicator variable } \\
\text { for plague periods }\end{array}$ & $\begin{array}{l}\text { Number of } \\
\text { observations }\end{array}$ \\
\hline \multicolumn{5}{|l|}{ BLACK DEATH } \\
\hline $\begin{array}{l}\text { Average annual rate } \\
\text { of real wage growth, } \\
\text { England, } 1310-1449 \text {, for } \\
\text { twenty year periods }\end{array}$ & $\begin{array}{c}0.70 \\
(0.43)\end{array}$ & $\begin{array}{c}0.12 \\
(0.65)\end{array}$ & -- & 6 \\
\hline \multicolumn{5}{|l|}{$\begin{array}{l}\text { Twenty-five year rates of } \\
\text { real wage growth, France, } \\
1313-1488^{\circ}\end{array}$} \\
\hline Workers nourri & $\begin{array}{c}0.12 \\
(0.17)\end{array}$ & -- & $\begin{array}{l}0.10 \\
(0.32)\end{array}$ & 7 \\
\hline Workers non-nourri & $\begin{array}{c}0.09 \\
(0.14)\end{array}$ & -- & $\begin{array}{c}0.09 \\
(0.25)\end{array}$ & 7 \\
\hline \multicolumn{5}{|l|}{ INFLUENZA } \\
\hline $\begin{array}{l}\text { Percentage changes in } \\
\text { acreage sown per capita, } \\
\text { for provinces in India, } \\
1916-17 \text { to } 1919-20^{c}\end{array}$ & $\begin{array}{l}-3.00 \\
(1.33)\end{array}$ & $\begin{array}{l}-0.25 \\
(0.28)\end{array}$ & -- & 13 \\
\hline
\end{tabular}


Notes:

Heteroskedasticity-consistent (White) standard errors are reported in parentheses below the coefficient estimates.

a. Average annual rates of growth of real wages in England were calculated from data reported in Hirshleifer (1987) on the average wages of unskilled agricultural workers employed on the estates of the bishops of Winchester for twenty-year periods from 1300 to 1459 . In calculating a wage growth series, we assigned the average wage for the period to the mid-point of the interval. The wages were deflated using the price of wheat. Population growth was derived from data reported in Russell (1948) and Hirshleifer (1987). Because the Black Death occurred so close to the endpoint of one of the twenty-year intervals under consideration, we grouped the periods 1330-49 and 1350-69 into one.

b. Wage growth in France was calculated from data reported in Robbins (1928) on the average nominal wages of workers nourri and of workers non-nourri, for twenty-five year periods from 1301 to 1500 . To calculate the series on wage growth rates, the average wage was assigned to the mid-point of the intervals. The wages were deflated using data on the price of poultry, also reported in Robbins (1928). Plague epidemics occurred in France during 1348-51, 1361, 1363, 1369, and 1371 (Robbins 1928, p.454).

c. Changes in acreage per capita in thirteen Indian provinces were calculated from data on changes in acreage sown (Schultz 1983, Sen 1967) and changes in agricultural population during the period 1916-17 to 1919-20 from data reported in Sen (1967). 